\title{
An Alkaline Solution of Potassium Chromate as a Transmittancy Standard in the Ultraviolet
}

\author{
Geraldine W. Haupt
}

\begin{abstract}
The need for a means of texting the reliablitty of the photonnetrle scalti of apectrophotometere in the ultraylojet reglon (where glaseeg are unsuitable) has led to the study of an aqueous bolution of potaskium chromate having the composition 0.0400 g/liter of $\mathrm{K}_{2} \mathrm{CrO}_{1}$ in $0.05 \mathrm{~N}$ KOIT. Based oll extensivo measuremente, lising photographici, photoelectric, and visual spectrophotometry, atandard values of apectral tranamittanoy have been determined tor 1.000 and $2,000 \mathrm{~cm}$ of solution at $25^{\circ} \mathrm{C}$ from 220 to $500 \mathrm{m \mu}$. These valuen have been tabulated along with derived values of absorbancy, molar abaurbantey index $a_{m}$ and $\log _{j 0} a_{y}$. The latter values have been compared graphically with those of other obaervers. Changes in spectral trinsmittsucy with changes is temperature bsve been detcrmined. The work has abo included a study of the efiects due to the contsiner bottle and to age of golutiong over periods up to 8 sears, and a comparison of reatilta obtained with the solution prepsired eitfer from $\mathrm{K}_{2} \mathrm{CrO}_{4}$ or from $\mathrm{K}_{2} \mathrm{Cr}_{1} \mathrm{O}_{3}$ as ont of the reapents.
\end{abstract}

\section{Introduction}

A means of testing the reliability of the photometris scale of spectrophotometers in the ultreviolet region has been in demand for a number of yeary. With the introduction of commercial photoelectric spectrophotometers for the uitraviolet in 1940, the demand increased considerably.

Although glass filter standarda of spectral transmittance $[1,2]$ ' have proved to be a very satisfactory and valuable means of testing the reliablity of the photometric scale of spectrophotometers in the visibte region, they are in general unsatisfactory in the ultraviolet. Not only do all but a few special glasses absorb completely below $290 \mathrm{~m} \mu$, but, in addition, the ultraviolet spectral transmittances of many glasses change on exposure to strong ultraviolet radiant flux $[2,3,4]$. In thess respects oolutions in cells with quartz end plates are found to be superior to glases for use in the ultraviolet. In addition, solutions are reproducible and can be prepared in the laboratory from specifications with reletively smiall time and cost. Various solutions have been studied or recommended ${ }^{2}$ a for this purpose. Preaminent among these is an aqueous solution of potagsitm chromete, $\mathrm{K}_{2} \mathrm{CrO}_{\mathbf{4}}(0.04 \mathrm{~g} / \mathrm{liter})$ in 0.05 $N \mathrm{KOH}$, This bas alternate ragions of high transmission and absorption in the ultraviolet, and this one solution in 1 - and $2-\mathrm{cm}$ thickmesses covers the transmittancy scale from about 0.90 to about 0.01 (0.048 to 2.0 in abarbancy). Several investigators have previously worked with this golution, and Irom the information available in 1940 this appeared to be one of the best for the purpose. It was accordingly selected for calibration.

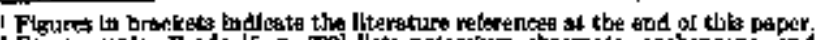

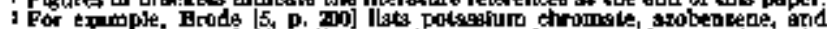

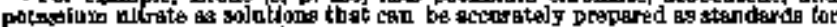
the cillbratlon of spevt ropbotometer.

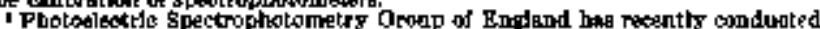

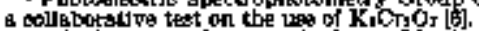

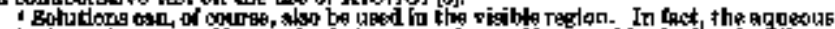

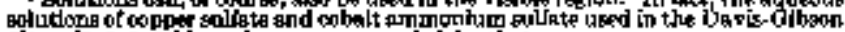

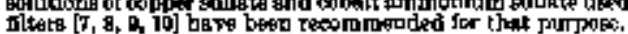

To mako the solution most useful as a calibration standard of spectral transmittancy in the ultraviolet, information should be available regarding jts permanence, or stability. lander specified conditions (including the effects of the conteiner bottles on the spectral transmittancy) and regarding any change in ifs spectral transmittancy with temperature over the range of room temperatures to be expected. Such data have accordingly been obtained.

This investigation was gtarted in 1940 and discontinued in 1943 because of the war. It was resumed in 1948 , and preliminary data have been published $[8,9.10]$. The present paper describes the work lesding up to the determination of these preliminary values, based solely on the measurements made in 1940-43, and describes the recent work on new solutions with a new instrument, on the basig of which tho final values wero derived as herein published.

\section{Preparation of Solutions}

Alt the potassiun chromate solutions atudied were prepared in the Bureau's Clemistry Division by W. Stanley Clabaugh. The solutions are of two gencrsl types (A) those prepared by dissolving the ealt in dilute solution of $\mathrm{KOH}$ and (B) those prepared by dissolving the salt in distilled water.

The type (A), or alkaline, solutions were prepared as follows:

$\left(\mathrm{A}_{1}\right)$ : A golution of $\mathrm{K}_{8} \mathrm{CrO}_{4}$ atock material, reagent grade, 0.0400 gliter, in $0.05 \mathrm{~N} \mathrm{KOH}$ (solution of potaseium hydroxide prepared by disalving $3.3 \mathrm{~L}$ of potassium hydroxide sticks ( $85 \% \mathrm{KOH}$ ) of rengent

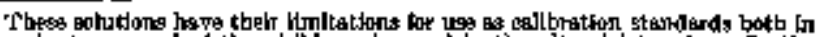

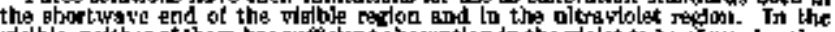

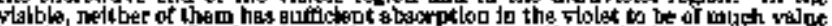

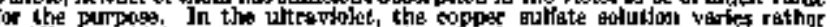

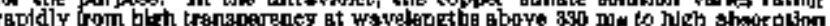

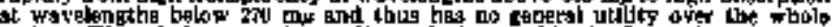

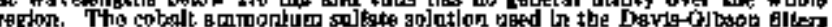

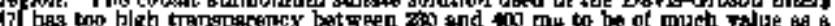
pest

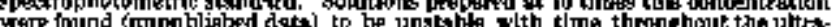

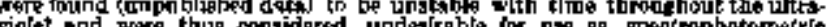
collheplan atandurds. 
quality in sufficient distilled water to make 1 liter).

$\left(\mathrm{A}_{2}\right)$ : A volution of $\mathrm{K}_{2} \mathrm{CrO}_{4}$ of the same concentration and alkalinity as $\left(A_{1}\right)$ but prepared from $0.0303 \mathrm{~g}$ of $\mathrm{K}_{2} \mathrm{Cr}_{2} \mathrm{O}_{7}{ }^{2}$, which, when converted gave $0.0400 \mathrm{~g}$ of $\mathrm{K}_{2} \mathrm{CrO}_{4}$ liter. This follows from the reaction $\mathrm{K}_{2} \mathrm{Cr}_{3} \mathrm{O}_{3}+2 \mathrm{KOH}=2 \mathrm{~K}_{2} \mathrm{CrO}_{4}+\mathrm{H}_{2} \mathrm{O}$.

The purpose of dissolving the potassium chromate in dilute solutions of $\mathrm{KOH}$ was to prevent any dichromate from forming. In $A_{5}$ a potassium chromate solution was prepared by means of a different material, potsssium dichromate. This solution was prepared to determine whother the sprctrophotometric data from $A_{1}$ and $A_{2}$ would be identical. Since they were found to be identical, there is a distinct advantage in using potsssium dichromate as one of the reagents rather than potassium chromate, because in stock materia] potassium diehromate exists in a purer state. A special sample of potessium chromate that had been recrystallized four times was used in the preparation of one of the $B$, or neutral, solutions with the riew to studying the effect of the purity of the potassium chromate.

The solytions prepared in 1940, 1942, and again in 1949 were stored in liter bottles of the ordimary storeroom glass type with glass stoppers. Fin further study of the effect of storage, half of the 1940 alkaline solution prepered from $\mathrm{K}_{2} \mathrm{CrO}_{1}$ and half of the 1040 neutral solutions were stored in similar bottles lined with ceresin. The tips of the rubber stopporg used were also covered with ceresin. Also half of the alkaline solutions prepured by methods $A_{1}$ and $A_{2}$ in $104 \theta$ were stored in alkali-resistant glaso (Corning gling 728).

None of the solutions was exposed to light except. when acturlly in use to fill the cells for their measurement. No solution was ever poured out-of itsobottle. In filing the cells a pipette was used to draw off the solution. Where flaking occurred; the sediment thus remajned on the bottom of the bottle. Each cell containing solution was measured relative to a similar cell contajníg distilled water.

The alkaline solutions are those from which the standard set of spentral trensmittancies yiven in table 1 were obtained. Although both alkaline and neutral solutions were prepared originally for the purpose of establishing standard spectral transmittancy datc. the neutral solutions were finally not used for that purpose. However, as the neutral golutions have been studied over a period of $8 \mathrm{years}$, a summary of the results on these is included in section 8.

\section{Methods of Measurement}

The solutions were messured on five instruments by three differont methods. One instrument operates by a photographic method, primarily for the ultraviolet region, but extending also into the violet and blue; one by a visual method; and three by photoelectric, one of these being for the visible range only.

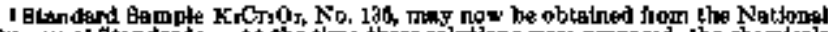

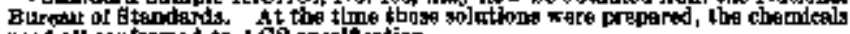
isod all contormed to ACB apectibetion.
}

\section{3:1. Photographic Method}

The photographic date were obtained by means of the Hilger sector photometer with the Fuess quartz spectrograph $[11,12,13]$.

The equivalent slit widths for an $0.2-\mathrm{mm}$ slit, which was used throughout all the exposures, are

\begin{tabular}{|c|c|c|}
\hline Wevelength & \multicolumn{2}{|c|}{ Slit. widtho } \\
\hline $\begin{array}{l}m \mu \\
400 \\
3] 0 \\
260 \\
220\end{array}$ & $\begin{array}{r}\mathrm{mm} \\
0.2 \\
.2 \\
.2 \\
.2\end{array}$ & $\begin{array}{l}m_{\mu} \\
\mathbf{0 . 6} \\
. \mathbf{2 5} \\
. \mathbf{3} \\
08\end{array}$ \\
\hline
\end{tabular}

On each plate exposures were made of at leagt two aluminum spark spectra for wavelength aalibration purposes. A calibration curve was used to translate scedar values, which were read at the density malchpoints, into wavelengths. Both1 1.000- and 4.000-cm cells were used with the Hilger instrument.

\subsection{Virual Method}

The König-Martens spectrophotometer $[13,14]$ is a visual instrument. The silt widthe used on this instrument are varied, depending upon the wavelength and the spectral characteristics of the sample being measured. With an incandescent source the efuivalent olit widthe in millimicrons used for two wavelengths and for two settings of the slits ara given bolow:

\begin{tabular}{|c|c|c|}
\hline Wavelength & \multicolumn{2}{|c|}{ Slit widthB } \\
\hline & $*$ & $\operatorname{mr}$ \\
$5 \pi \mu$ & $\min$ & 2.7 \\
500 & 0.5 & 2.7 \\
\hline
\end{tabular}

The mercury are, also available for use on this instrument, enables transmittancy measurements to be made that are not subject to possible wavelength or slit-width errors.

Two cell lengths were used with this instrument. namely, 4.000 and $10.000 \mathrm{~cm}$.

\subsection{Photoelectric Method}

\section{a. Erackakt Quarts Double Monochromator and Auxiliary Equifiment [I5]}

The source of illumination used was a special incandescent lamp, with a quartz window, which opcraterd on a 120-volt, 45-ampere battery. The monochromator has three slit systems. The exit slit next to the photoelectric tube was kept at a constant mechanical width for nearly all the measurements, and the other two were varied concurrently. Any stray enersy that passes the second slit is effectively elimnated from reaching the exit slit by the use of the second spectrometer provided on this instrument. 
The instrument operates with a single wavelength control. Spentral bands transmitted by the slits were comparable in width $(m \mu)$ to those obtaingd with the photographic method. A photoelectric cell of the electron-emission type was used as detector and palues of apectral transmittancy were obtained by means of the ration-of-deflections method with a high-sensitivity galvanometer.

The gcale for reading or setting wavelengths on this monochromator is a linear one (not direct reading in millimicrons) and a wavelength calibration curve of the instrument was already available" This curve was based upon acalar gattings previously determined for mercury lines down to $237.8 \mathrm{m \mu}$. As the incindescent lamp was the only source of irradiation for the spectrophotometric work, the wavelength calibration was frequently checked at one wavel angth (557 $\mathrm{m \mu}$ ) by meane of two particular stendard glasses whose spectril transmittances are known to be the seme at that wavelength. Tho linear correction determined at this wavelength was then epplied to the whole scale.

The lower end of the wavelength ealibration curve was extrapolated below $237.8 \mathrm{~m} \mu$ for thege mensurements, and the date in this region with the Brackett instrument are therefore of lesser validity.

\section{b. General Electric Aecording Spectrophatometey}

The General Electrìc recording apectroplotometer has been degeribed in a series of three papers [18, 17, 18]. The data obtained with this instrument are for the visible range only and extend from 400 to $750 \mathrm{~m} \mu$. Checks on the wavelength scale were made in the uвual manner by using a calibrated didymium glas. A nominal slit width equivalont to epprorimately $4 \mathrm{~m} \mu$ wes ueed throughout the recordings. Cellg of 1.000-cm thickness were used for the measurements:

\section{a. Beoknan Quarts Spectrophotometer (Model DU)}

The Beckman spectrophotometer has been deseribed in a paper by Cary and Becktnan [19]. Transmission measurements with a modification of this instrument, which has a constant-tempersture enclosure ${ }^{7}$ designed and construeted at the National Bureau of Standards, have been degcribed in detail in a paper by Gibeon and Bnleom [20]. All measurements on the Beckman spectrophotometer were made with a $1.000-\mathrm{cm}$ cell. The cell holder is kept constant at $25^{\circ} \mathrm{C}$ or other desired temperature by means of water pumped through from a constant-temperature beth.

For wavelength checks the $\mathrm{Hg}$ green line (546.1 $\mathrm{m}_{\mu}$ ) was used. When necegsary, the whole wavelength scale was adjusted by the slight turning of

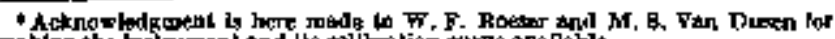

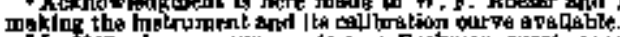

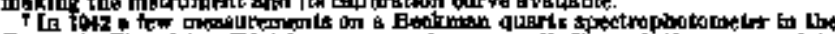

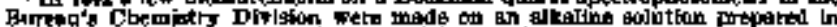

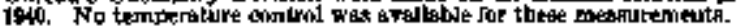

the internal ecrew that rotated the collimating mirror. After such check or adjustment, the procise wavelength correction was then applied at each warelength setting in accordence with the curve illustrated in figure 6 of reference [20].

For transmittancy measurements three sources are available, namely, the incundescent-filament lamp, the hydrogen are, and the mercury are, all as supplied by the maker. The incandeseent and hydrogen sources were used over the appropriate wavelength ranges, overlapping from 320 to $380 \mathrm{~m} \mu$. The s]it widthg with these sources nerer exceeded $2 \mathrm{~m}_{k}$ and were usually lese than $1 \mathrm{~m}_{k}$. The mercury are was also used for trangmittancy measurements at certain wavelengths as noted below.

A cloar quartz lens similar to that supplied with the instrument was used to effect an approximate collimation of the beam. Over the wravelength range from 330 to $420 \mathrm{~m}$ with the incandescent souree and from 360 to $380 \mathrm{~m} \mu$ with the hydrogen souree, a parple (Corning filter No. 9863) lens was used to reduce stray light as well as to collimate the bearn.

\section{Standard Spectrophotometric Data}

In examining the data obtained during the first two years of the investigation, the type A, or alkaline, golutions were found to give more reproducible results (i. e., less scattering of data on repeated messurements) than the type B, or neutral, solutions. Furthermore, the alkalune solutions were found to give a better range of transmittencies in the extreme ultraviolet than the neutral solutions. Since the alkaline solutions were thus found to fulfill more noarly the requirements of a standard of spectral transmittancy in the ultraviolet, all later work and all the detailed dats to be presented refer to the alkaline colution of potessium chromate ( 0.04 g/titer in 0.05 $N \mathrm{~K}(\mathrm{H})$.

As already noted, the work on the 1940 and 1942 solutions Was interrupted in 1943. Sufficient dats were obtained, however, that a tentative set of spectral transmittancy values could be evaluated. These values are given ${ }^{8}$ in column 2 of table 1 , desigmated as $T_{1}^{\prime}$ Ther were read from a curve, of which figure $1 \mathrm{is}$ a tracing. The individual deterninations by the five instruments. used are plotted and may be identified from the legend. These tentative values thus represent a graphical average of al] these earlier data. Mensurements were made on the 1940 aolutions a few days after their preparation and then again at the end of $2,4,7,8$, and 10 months, 2 years 4 monthe, 2 years 5 months, and 2 years 7 months. The 1942 solutione were measured a few days after their preparation and again in 1,2 , and 6 months.

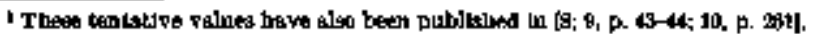




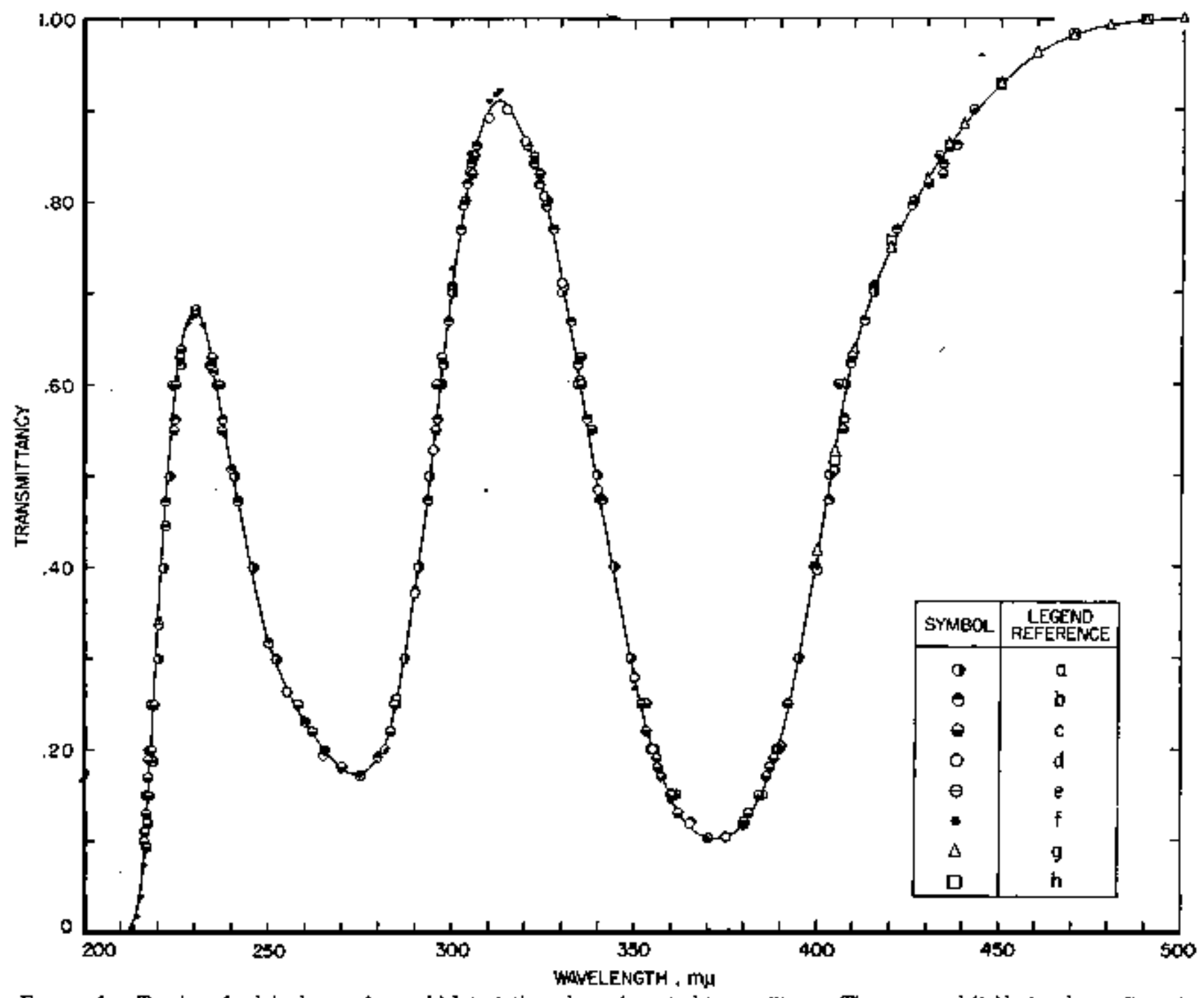

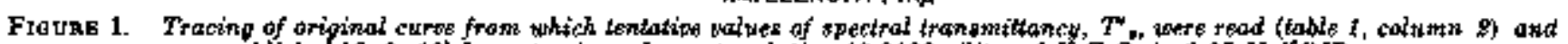

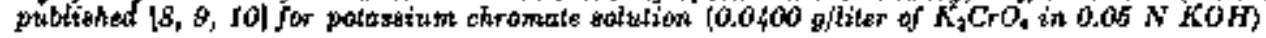

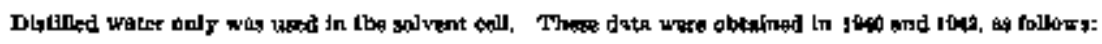

\begin{tabular}{|c|c|c|c|c|c|}
\hline & Spectropbotoraetert & 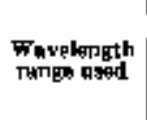 & $\begin{array}{l}\text { Alikitine } \\
\text { solutikn } \\
\text { segpared }\end{array}$ & $\underset{\text { Denth }}{\text { Dell }}$ & $\begin{array}{l}\text { Nuraber } \\
\text { of dater- } \\
\text { minit- } \\
\text { tions jep } \\
\text { Jeeerited }\end{array}$ \\
\hline D & $\begin{array}{l}\text { Higer westor photor } \\
\text { meter fphototgesph- }\end{array}$ & 215 to 150. & $\begin{array}{l}h_{1}, 1940 \ldots \\
h_{1}, 1040 \ldots\end{array}$ & en & $\beta$ ta 7 \\
\hline b & nis- & & 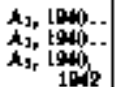 & I & $1 \quad \begin{array}{c}1 \\
\operatorname{lon} 3\end{array}$ \\
\hline 4 & $\begin{array}{l}\text { Ensoisett double moos- } \\
\text { chromatar iphoto- } \\
\text { éleotylo). }\end{array}$ & 200 to $40 \mathrm{~N} .7$. & 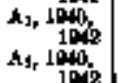 & $\begin{array}{l}1 \\
\mathbf{I}\end{array}$ & 2 ta \\
\hline B & Bectman iphotoeler & $\begin{array}{l}\text { Adjugted be } \\
\text { bow } 240 \text {. } \\
213 \text { to } \$ 00 . . .\end{array}$ & 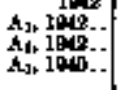 & i & $\begin{array}{l}2 \\
1\end{array}$ \\
\hline a & 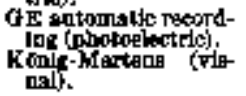 & 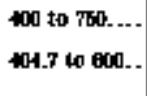 & 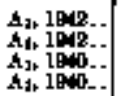 & $\begin{array}{l}1 \\
1 \\
10\end{array}$ & $\left\{\begin{array}{l}1 \\
1 \\
\tan 4\end{array}\right.$ \\
\hline
\end{tabular}




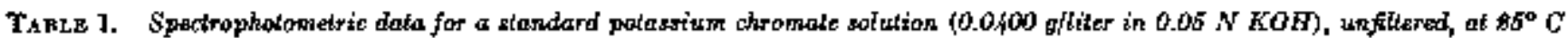

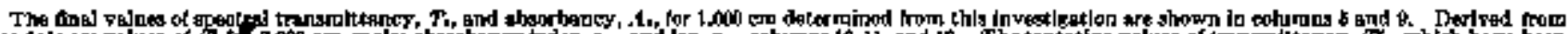

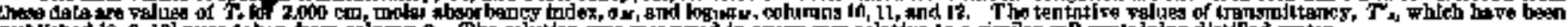

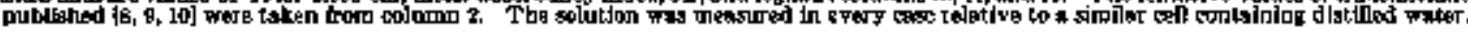

\begin{tabular}{|c|c|c|c|c|c|c|c|c|c|c|c|}
\hline \multirow{4}{*}{ 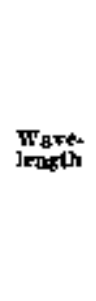 } & \multicolumn{7}{|c|}{ Tranamittancy, $T$, toe $1.000 \mathrm{cun}$} & \multirow{4}{*}{ 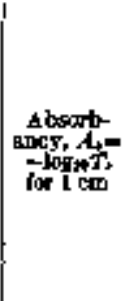 } & \multirow{4}{*}{ 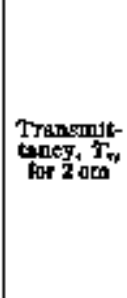 } & \multirow{4}{*}{ 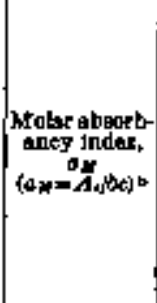 } & \multirow{4}{*}{$\log \Delta a x$} \\
\hline & \multirow{3}{*}{ 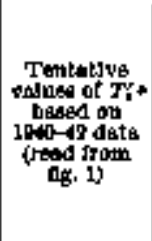 } & \multicolumn{2}{|c|}{ 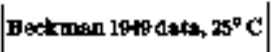 } & \multirow{3}{*}{ 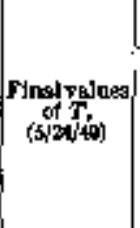 } & \multicolumn{3}{|c|}{ 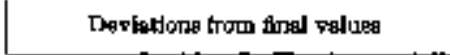 } & & & & \\
\hline & & \multirow[b]{2}{*}{ Ha bourse } & \multirow[b]{2}{*}{ 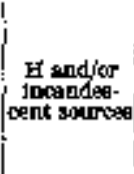 } & & \multirow[b]{2}{*}{$\begin{array}{c}184(1)-42 \text { deta } \\
(7)-(6)\end{array}$} & \multicolumn{2}{|c|}{ IOHe Beckman } & & & & \\
\hline & & & & & & 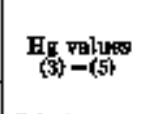 & 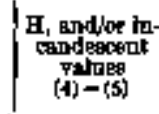 & & & & \\
\hline 1 & 2 & 3 & 1 & 5 & 6 & 7 & $*$ & o & 10 & J1 & 12 \\
\hline $\begin{array}{c}77^{40} \\
160 \\
30 \\
20 \\
20\end{array}$ & $\begin{array}{l}0.000 \\
-.005 \\
.35 \\
.60 \\
.020\end{array}$ & 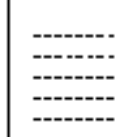 & $\begin{array}{l}0.076 \\
.358 \\
.801 \\
.885\end{array}$ & 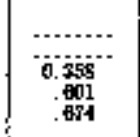 & 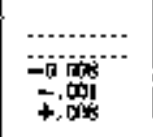 & 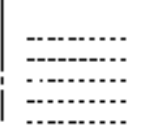 & 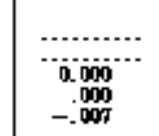 & 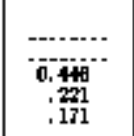 & \begin{tabular}{l}
$\cdots . .$. \\
\hdashline 0.198 \\
.391 \\
.154
\end{tabular} & 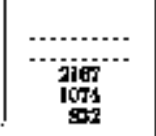 & 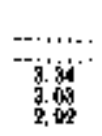 \\
\hline 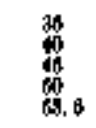 & $\begin{array}{l}.617 \\
-800 \\
-.010 \\
.210 \\
.290\end{array}$ & \begin{tabular}{l}
$0 .-$ \\
\hdashline 0.978
\end{tabular} & $\begin{array}{l}.815 \\
.505 \\
.398 \\
.919 \\
.280\end{array}$ & 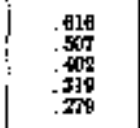 & $\begin{array}{r}+.000 \\
+.002 \\
+.000 \\
.000\end{array}$ & 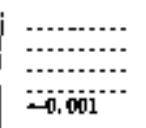 & $\begin{array}{r}-.001 \\
=.002 \\
-.005 \\
-.000 \\
+.0013\end{array}$ & $\begin{array}{l}.210 \\
.295 \\
.326 \\
.596 \\
.596\end{array}$ & $\begin{array}{l}.379 \\
-395 \\
-160 \\
.102 \\
.058\end{array}$ & 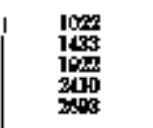 & 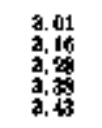 \\
\hline 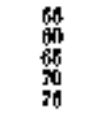 & $\begin{array}{l}.2938 \\
.232 \\
.201 \\
.390 \\
.173\end{array}$ & 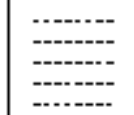 & $\begin{array}{l}.289 \\
.2304 \\
.289 \\
.279\end{array}$ & 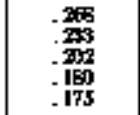 & $\begin{array}{l}-.000 \\
=-800 \\
-.000 \\
-.002\end{array}$ & 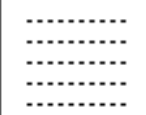 & $\begin{array}{r}.000 \\
+.001 \\
+.002 \\
+.001 \\
+.003\end{array}$ & $\begin{array}{l}.57 \\
.673 \\
.650 \\
.745 \\
.755\end{array}$ & 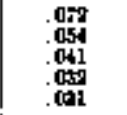 & $\begin{array}{l}2778 \\
30072 \\
3354 \\
33617 \\
3678\end{array}$ & 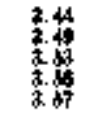 \\
\hline 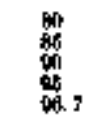 & $\begin{array}{l}.189 \\
.290 \\
.872 \\
.629 \\
.690\end{array}$ & 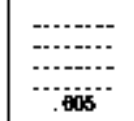 & $\begin{array}{l}.198 \\
.291 \\
.379 \\
.530 \\
.600\end{array}$ & $\begin{array}{l}.194 \\
.255 \\
.273 \\
.373 \\
.398 \\
.398\end{array}$ & $\begin{array}{l}=.005 \\
=.006 \\
=.010 \\
=.001 \\
=.008\end{array}$ & 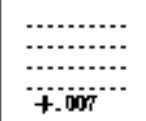 & $\begin{array}{l}+.005 \\
+.004 \\
+.001 \\
+.0000 \\
+.000\end{array}$ & $\begin{array}{l}.712 \\
.380 \\
.828 \\
.223 \\
.223\end{array}$ & 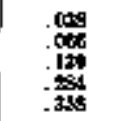 & 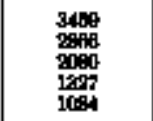 & 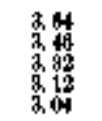 \\
\hline $\begin{array}{l}200 \\
0.2 \\
06 \\
0.9 \\
10.2\end{array}$ & $\begin{array}{l}.709 \\
.7784 \\
.831 \\
.8909 \\
.8909\end{array}$ & 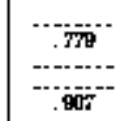 & $\begin{array}{l}.710 \\
.70 \\
.899 \\
.897\end{array}$ & 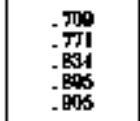 & 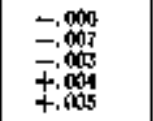 & 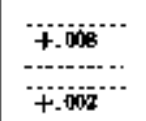 & $\begin{array}{r}+.001 \\
-.001 \\
-. .000 \\
-. .08\end{array}$ & $\begin{array}{l}.140 \\
.6213 \\
.048 \\
.043\end{array}$ & 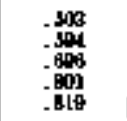 & 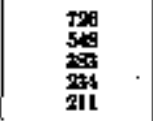 & 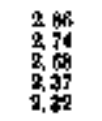 \\
\hline $\begin{array}{l}15 \\
20 \\
25 \\
25 \\
20.2\end{array}$ & $\begin{array}{l}.894 \\
.869 \\
.810 \\
.715 \\
.992\end{array}$ & 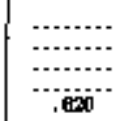 & 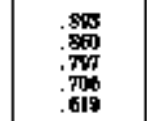 & 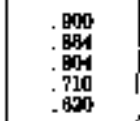 & 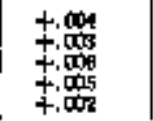 & 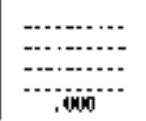 & 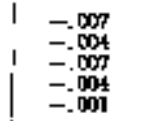 & 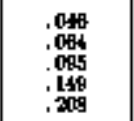 & 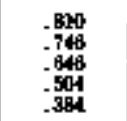 & $\begin{array}{l}\frac{922}{202} \\
200 \\
700 \\
7006\end{array}$ & $\begin{array}{l}2.25 \\
2.40 \\
2.40 \\
2.86 \\
3.00\end{array}$ \\
\hline $\begin{array}{l}45 \\
40 \\
5 \\
50 \\
55\end{array}$ & $\begin{array}{l}.605 \\
.490 \\
.291 \\
.201 \\
.202\end{array}$ & 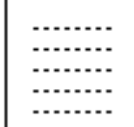 & 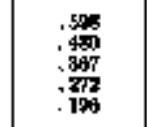 & 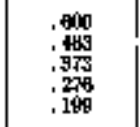 & 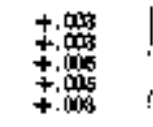 & 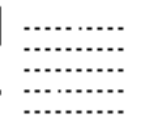 & $\begin{array}{l}-.002 \\
=.003 \\
-.000 \\
-.004 \\
-.000\end{array}$ & $\begin{array}{l}.222 \\
.316 \\
.428 \\
.595 \\
.501\end{array}$ & $\begin{array}{l}.390 \\
.293 \\
.139 \\
.0290 \\
.040\end{array}$ & 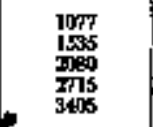 & 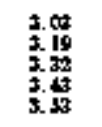 \\
\hline $\begin{array}{l}60 \\
65 \\
70 \\
75 \\
80\end{array}$ & $\begin{array}{l}109 \\
: 110 \\
: 102 \\
: 1108 \\
1108\end{array}$ & 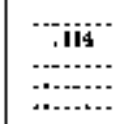 & $\begin{array}{l}.148 \\
.116 \\
: 104 \\
: 102\end{array}$ & $\begin{array}{l}1118 \\
: 110 \\
: 109 \\
: 102 \\
1197\end{array}$ & 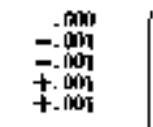 & 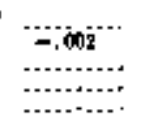 & 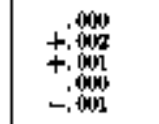 & .\$口 & $\begin{array}{l}.022 \\
.011 \\
.011 \\
.014 \\
.014\end{array}$ & 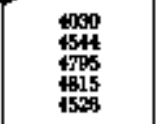 & $\begin{array}{l}3.81 \\
3.46 \\
3.86 \\
3.8 \\
3.4\end{array}$ \\
\hline$\underbrace{\infty}_{0.7}$ & 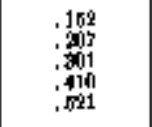 & 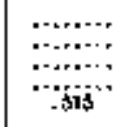 & $\begin{array}{l}-147 \\
-198 \\
-287 \\
-39 \\
-3010\end{array}$ & 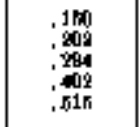 & $\begin{array}{l}+.002 \\
+.000 \\
+.007 \\
+.000 \\
+.006\end{array}$ & "an & $\begin{array}{l}=.000 \\
=.000 \\
=.000 \\
=.007\end{array}$ & 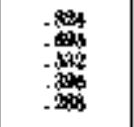 & 的 & 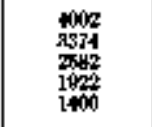 & $\begin{array}{l}3.00 \\
3.69 \\
3.41 \\
2.8 \\
2.35\end{array}$ \\
\hline $\begin{array}{l}10 \\
200 \\
20.8 \\
20.8 \\
40\end{array}$ & 的 & 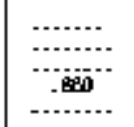 & $\begin{array}{l}-890 \\
-864 \\
-894 \\
-856 \\
-890\end{array}$ & $\begin{array}{l}.809 \\
.851 \\
.859 \\
.8992\end{array}$ & $\begin{array}{l}+.000 \\
+.0002 \\
+.000 \\
+.002 \\
+.002\end{array}$ & & $\begin{array}{r}-.001 \\
+.000 \\
-.000 \\
-.000\end{array}$ & $\begin{array}{l}.103 \\
.124 \\
.004 \\
.066 \\
.046\end{array}$ & 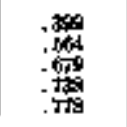 & 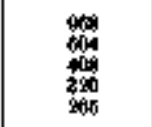 & 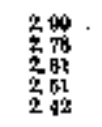 \\
\hline $\begin{array}{r}s \\
b \\
70 \\
70 \\
\$ 0 \\
\infty 0\end{array}$ & $\begin{array}{l}.829 \\
.629 \\
.881 \\
.102 \\
.806 \\
1.000\end{array}$ & 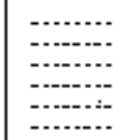 & $\begin{array}{l}.8283 \\
.859 \\
.9790 \\
.990 \\
.8909\end{array}$ & $\begin{array}{r}.97 \\
.900 \\
.960 \\
.900 \\
.000\end{array}$ & $\begin{array}{l}+.001 \\
+.001 \\
+.001 \\
+.001 \\
+.001 \\
+.001\end{array}$ & 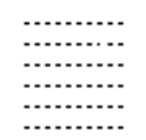 & $\begin{array}{r}-.001 \\
=.001 \\
-.001 \\
-.001 \\
-.001 \\
-.001\end{array}$ & $\begin{array}{l}.093 \\
.018 \\
-000 \\
-004 \\
-004 \\
.001 \\
.000\end{array}$ & 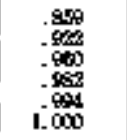 & $\begin{array}{c}160 \\
\$ 90 \\
4 \\
19 \\
6\end{array}$ & $\begin{array}{c}2.20 \\
1.00 \\
1.80 \\
1.20 \\
.60\end{array}$ \\
\hline
\end{tabular}

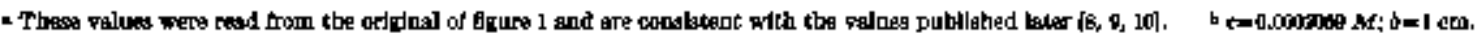


In April 1949 four sels of data were taken on the Beakman spectrophotometer [20], one on each of freahly prepared alkaline ( $A_{1}$ and $A_{n}$ ) solutions majntained at $25^{\circ} \mathrm{C}$, stored both in gyase and alkaliresistant ware.

The four gets of data were averaged. Values obtained with the mercury source are listed in column 3 of table 1; values obtained with the hydrogen and for incandescent sources are listed in column 4.

The final values of $T$, shown in column 5 were derived according to the following procodures:

(a) At the mercury wavelengtha, a straight average of three sets of data, namely, (1) 1949 Beckman data with mercury line sourec (column 3); (2) 1949 Beakman data with hydrogen and/or incandescent continuous-spectrum source (column 4); (3) Tentative values based on $1940-42$ data, $T_{*}^{*}$, (column 2 ).

(b) At other wavelengths above $220 \mathrm{mp}$ (with the exception of 295 to 315 ) a straight average of two sete of data, nemely, (1) 1949 Beckman data witlu lydrogen and/or incandescont soluee (column 4); (2) Tentative values based on $1940-42$ data, $T$. (eolumn 2).

At 295, 300, 305, 310, and $315 \mathrm{~m} \mu$ slight further adjugtments in, $T$, (not exceeding 0.003 ) were madc to bring the final values into better agreement with the averages obtained at the mercury wavelengths, using procedure (a).

Columns 6, 7, and 8 of table 1 show the deviations of the three sets of data from the final values. It is eviderit that there may be considerable uncertainty in the third decimal of column 5 .

Values of apectral absorbancy, $A_{f}$, for a $1.000-\mathrm{cm}$ thickness of solution are given in column 9 . These values of $A$, were derived from the relation $A,=-\log _{10} T$, . To cover the photometric scale below $T_{t}=0.10$, values of transmittancy for a $2.000-\mathrm{cm}$ cell were computed and are given in column 10.

Column 11 gives values of the molar-absorbancy index [21] $a_{\mu}=A_{c} / b c$ where $c$ is the eoncentration expressed it moles per liter, and $b$ is the cell thickness in centimeters. Column 12 gives the values of $\log _{1 m} a_{s r}$.

\section{Comparison of Data with Those of Other Observers}

T'abular data on the spectral transmittancy of potassium chromate in $0.05 N$ potassium hydroxide have been published by von Halban and siedentopt [22], Rössler [23], Bajy, Morton, ankl Riding [24], and Hogness, Zsebeile, and Sidwal] [25].

Hogness, Zscheile, and Sidwell used a plotoelectric method for their determinations, The potassium chromate was recrystallized four and five times. They khow the abeorption spectrum for this solution in a figure [25]. The dotg through which the curve is drawn in their figure are taken from several series of determinations at $2.5-\mathrm{m}_{\mu}$ intervals from 220 to $410 \mathrm{mp}$. Values of molar extinction for the maxima and minims and for 366 and $265 \mathrm{m \mu}$ were given in tabular form. The experimental conditions under which these tabulated data were obtained are given in table 2 .
Figure 2 compares the present data with those already published in tabular form. $\log _{10} a_{N}$ is used for this comparison in accord with the practice used in the International Critical Tables [26]. The methads used in the varions atudies are shown in the caption.

TABLE 2. Experimental condfítons water which terloin dato of Hognets, 28theile, ond Sfutweld [25] were obtained

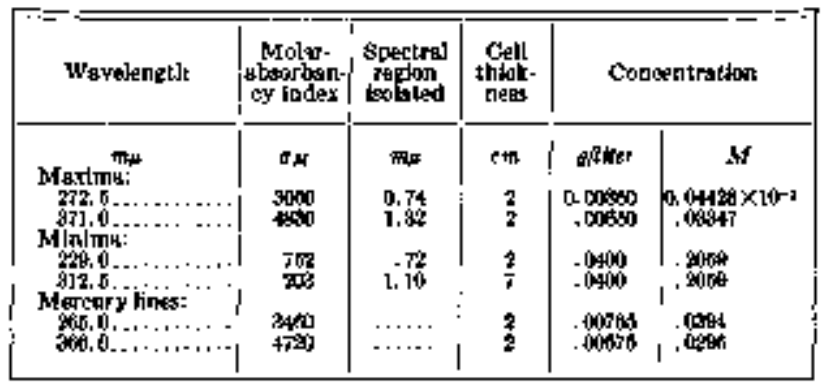

From figure 2 it may be scen that in general the agreament, in $\log _{10} t_{N}$ from 220 to $450 \mathrm{~m}_{\mu}$ found by the fire investigators shown is quite close, with the exception of a few points, Below $300 \mathrm{In} \mu$, two values of von Halban (photoclectric method) at 254 and $265 \mathrm{~m} \mu$ are at variance with the rest. Above 300 $\mathrm{m}_{\boldsymbol{\mu}}$, the value of BaJy, Morton, and Riding (photographic method) at $313.2 \mathrm{mp}$, serns erroneous. Most of the 16 wavelength values of Rogaler from 381.5 to $439.0 \mathrm{~m} \mu$ will be seen to be lower in $\log _{30} a_{M r}$ than those of the others shown. In his peper. Robsler has put these wavelengths in parenthoses; apparently these were an indicated because of the relatively low dispersion of the prism in his instrument.

In the present. investigation only a single concentration of potaseium chlomate was used. No attempt was mede to cari's out a study of conformity to Beer's law, becauga the one solution in 1- and 2-cm thicknesses covered the photometric range of interest. However, it was known that Hogness, Zscheile, and Sidwell had made a run on exactly the same concentration usad by won Haban and found good agreement with their curve [25] obtained from data on optumum concentration. From these data it was roncluded that Beer's law held. Results hive also heen pub]ighed [27] of Bepr's law tests on potassium chronate in $0.05 N^{\top} \mathrm{KOH}$ at $372 \mathrm{~m} \mu$. Various dilutions were used, and the regults are given in both tahular and grapbianal forms. The moleeular concentrations used raried from $1.61 \times 10^{-6}$ to $51.5 \times$ $10^{-5}$. This corresponds to variations in encentration from 0.00313 to 0.1000 gliter. Determination of this complianee with Beer's law was made as a means of checking the photometric reproducibjlity of a nmw spectrophotoneter.

\section{Effect of Temperature on Spectral Transmittancy}

Because it was desirable to know whether or not the potassium diromate solution for use as a calibration standard changed in spectral transmittancy 


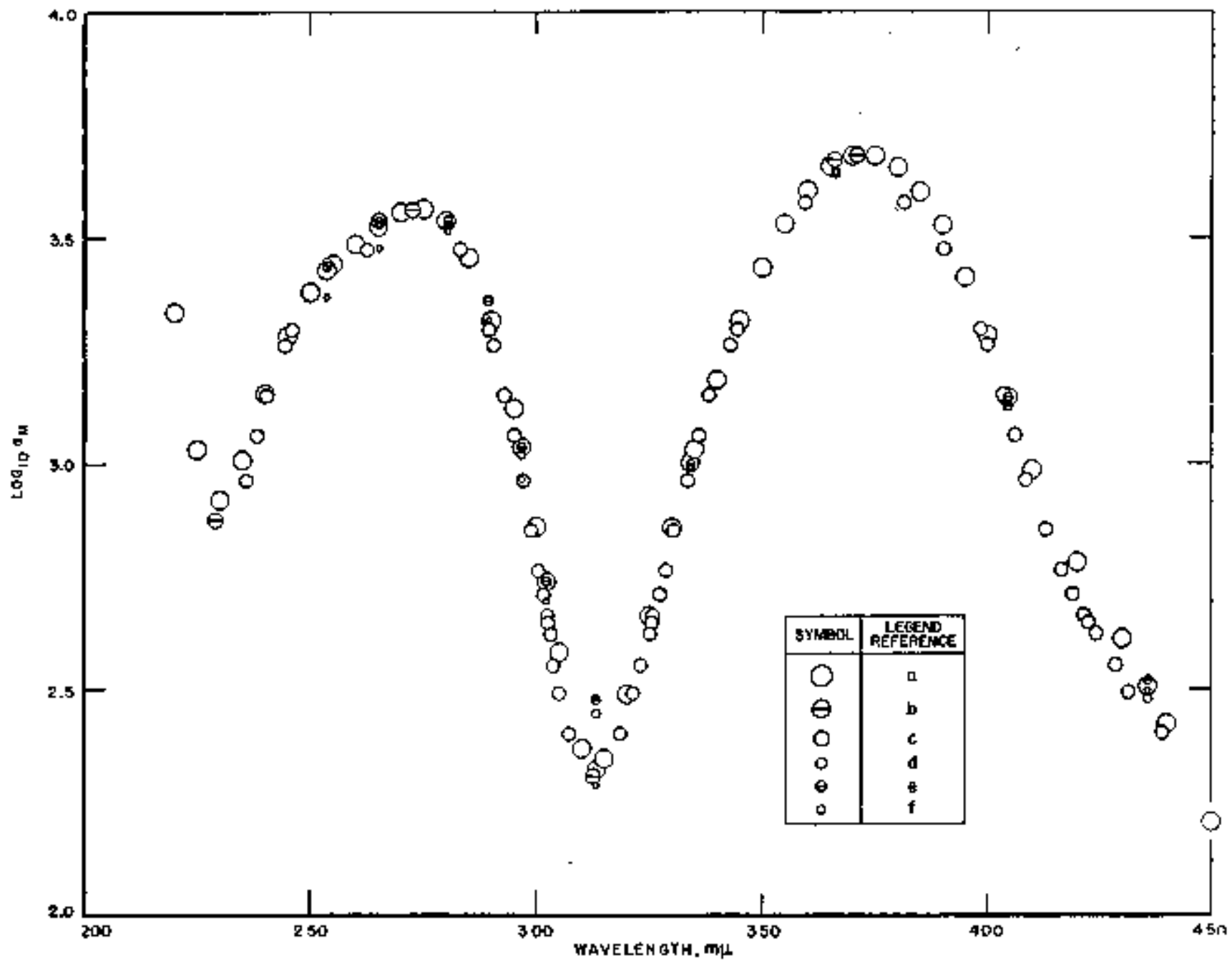

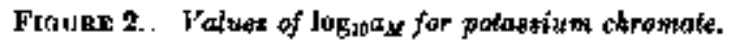

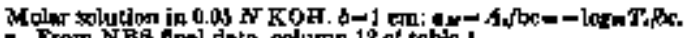

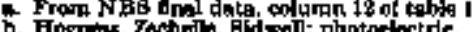

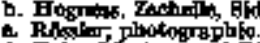

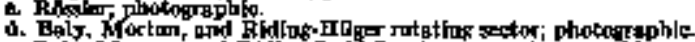

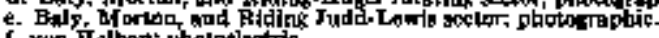

f. woun indbed; wholpelextric.

with change in temperature, several preliminary fests were made in 1948 on the 1942 solutions by means of the Beckman spectrophotomoter [20]. The resulting data indicated that the largest effects due to changea in tenperature occur below $235 \mathrm{~m}_{\mathrm{k}}$.

A more detailed and complete study of the change in spectral transmittancy with temperature was then made for the 1949 alkaline eolutiong of both twpes stored in alkaj-resistant bottles. The wavelength range from 215 to $500 \mathrm{~m} \mu$ was studied for approximately a 25-deg change in temperature. The epectrul-transmittancy data were determined for one solution over a definite wavelength range at $25^{\circ}, 50^{\circ}$, and again at $25^{\circ} \mathrm{C}$ in a single day. Each change in spectral transmittancy for an approximately 25 dec change in temperature was computed separately for each day's set of meserrements. Three sets were areraged and are plotted in large circles in figure 3 .

Included in the figure are also points obtained from the measurements made on the 1942 alkaline bolutions at various times at each of the temperatures, $25^{\circ}$ and $50^{\circ} \mathrm{C}$. These data cortoborate the data obtained with the 1949 solutions. It may be of interest to point out that the changes in trensnlittancy with increase in temperature shown in figure 3 are such as to indicste a shift of the absorption bands toward longer warelengths.

The curve shown in figure 3 was then drawn, from which values of $\Delta T$, for a change of 25 deg were read. Values of $\Delta T$, for a change of $10 \mathrm{deg}$ werc computod from these eurse readings by lincar interpolation, and the resulting data are given in table 3 . Users of the stapdard solution should 


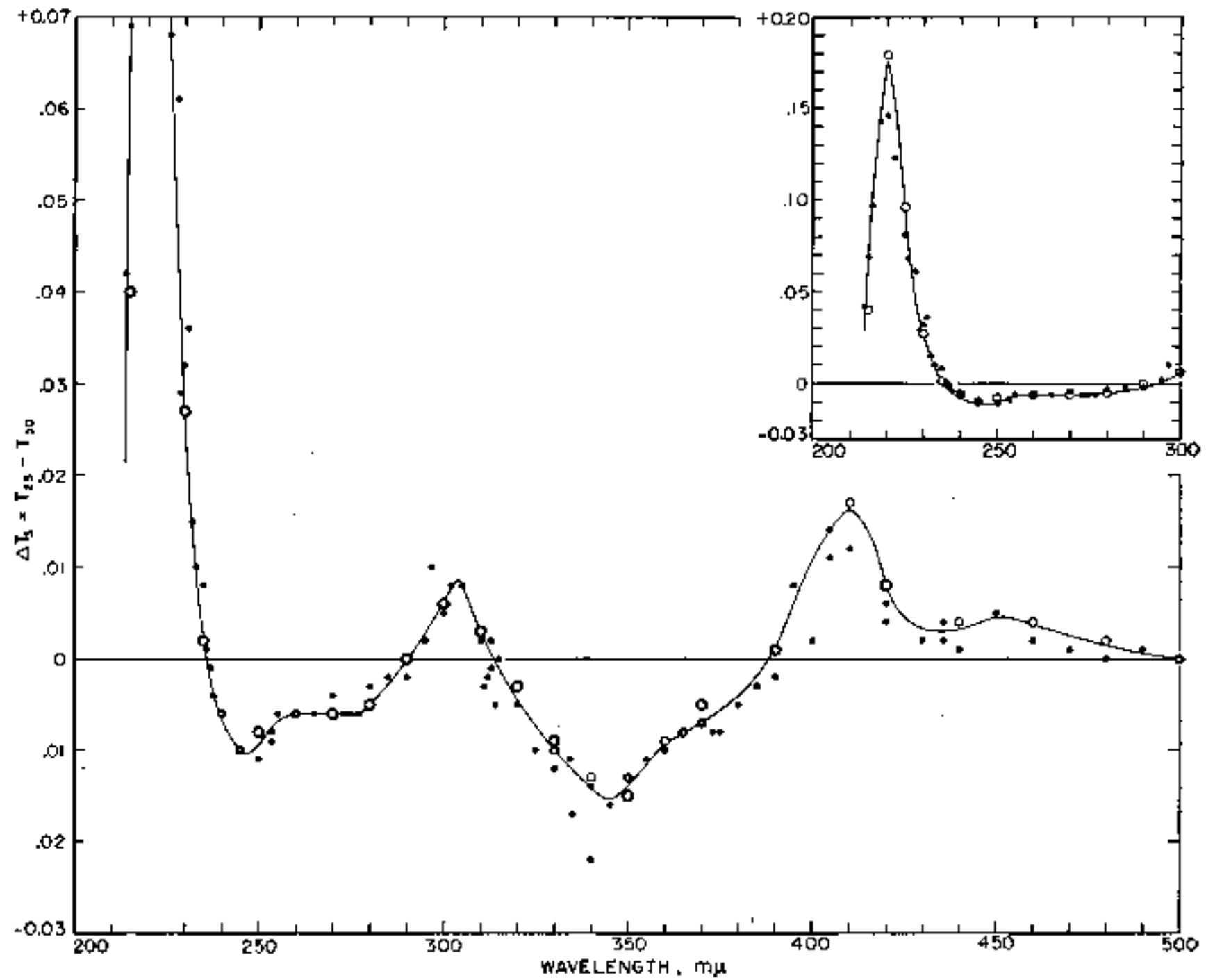

F1oure a. Change in spactral trantmitlaney for a ekange in temperature of $\$ 5^{\circ} C$.

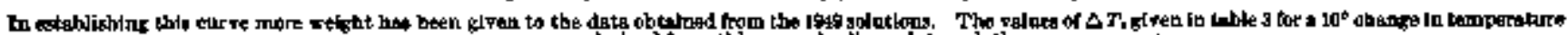
wers deriped trom this carve by Encar laterpolation.

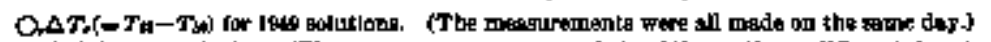

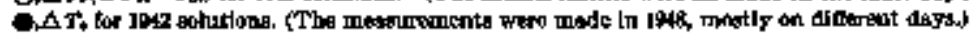

make use of these corrections proportionately whenever the temperature of the solution doviates importantly from $25^{\circ} \mathrm{C}$. Values of $\Delta A$, in tablo 3 are derived from the values of $\Delta T$, by the refation.

$$
\Delta A_{4}=-\log _{10} e \frac{\Delta T_{1}}{T_{\text {(ISP) }}}
$$

\section{Permanence}

Measurements have been made from lime to time on these alkaline solutions, and the study hag included effects due to the storage of some of the solutions over periods up to 8 years. The 1940 alkaline solution made from $\mathrm{K}_{2} \mathrm{CrO}_{4}$ in $\mathrm{KOH}$ was stored both in an ordinary glase bottle and in a similar bottle lined with ceresin. The 1940 alkaline eolution made from $\mathrm{K}_{2} \mathrm{Cr}_{3} \mathrm{O}_{7}$ and the 1942 alkaline solutions made both from chromate and dichromate were stored only in ordinary glase bottles.

Above $260 \mathrm{~m} \mu$ no definite change in spectral trans. mittancy was found for the solutions gtored in glass. Below $260 \mathrm{~m}_{\mu}$ the 1940 alkaline solutions showed definite changes at the end of 8 yenrs of storage in glass bottles, the solution made from the dicliromat exhibiting the smaller change. The fact that potassium dichromate in stock material exists in a purer state may account for this solution being more stable. However, the 1942 alkaline solutions of both types likewise atored in glasg bottles showed little if any change in spectral tranamittancy over a period of 6 years. 
TApLv 8. Values of $\Delta T_{,}\left(-T_{\mathrm{H}}-T_{34}\right.$ or $\left.T_{96}-T_{56}\right)$ for a $10^{\circ} C$ change in temperoture corresponding to tuaveleagh diated

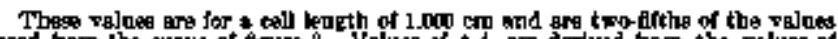

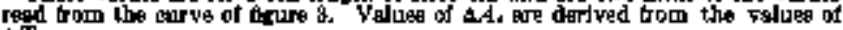
$\Delta \mathrm{T}$

\begin{tabular}{|c|c|c|c|c|c|}
\hline $\begin{array}{l}\text { Wave- } \\
\text { jeneth }\end{array}$ & $\begin{array}{l}\text { valuseg ot } \\
\Delta T_{4} \text { for } \\
\text { Io dec. C }\end{array}$ & $\begin{array}{l}\text { Valoes of } \\
\text { AA.tor } \\
\text { lit dee. C }\end{array}$ & $\begin{array}{l}\text { Wrase } \\
\text { leopth }\end{array}$ & $\begin{array}{l}\text { Valueg of } \\
\text { AT, toe } \\
10 \text { deE } C\end{array}$ & $\begin{array}{l}\text { Velueg of } \\
\text { Afd for } \\
10 \text { der. C }\end{array}$ \\
\hline min & & & ${ }_{330}$ & $.00+1$ & onst \\
\hline $\begin{array}{l}15 \\
200 \\
25 \\
30\end{array}$ & $\begin{array}{c}+0.085 \\
-670 \\
-605 \\
.6100\end{array}$ & $\begin{array}{c}-0.28 \\
.024 \\
.006 \\
.0065\end{array}$ & $\begin{array}{l}322 \\
36 \\
4\end{array}$ & $\begin{array}{l}.00 \mathrm{Y} \\
.00+80 \\
.0056\end{array}$ & $\begin{array}{l}.0005 \\
.0005 \\
.0060\end{array}$ \\
\hline $\begin{array}{l}35 \\
30 \\
45\end{array}$ & $\begin{array}{l}+.0010 \\
-.0003 \\
.0040\end{array}$ & $\begin{array}{l}=.000 i \\
+.0002\end{array}$ & $\begin{array}{l}50 \\
55\end{array}$ & .00060 & $\begin{array}{l}.1072 \\
.1000 \\
-0009\end{array}$ \\
\hline $\begin{array}{l}30 \\
53.6 \\
53.6\end{array}$ & - 00038 & .0061 & 60 & .0005 & $\begin{array}{l}0.07 \\
-0120 \\
-012\end{array}$ \\
\hline 65 & $\begin{array}{c}002 \pi \\
.0024 \\
-0024\end{array}$ & .0044 & 撖 & .0022 & $\begin{array}{l}-0003 \\
.0068\end{array}$ \\
\hline 督 & $\begin{array}{l}-.003 \\
.0023\end{array}$ & . & $\begin{array}{l}85 \\
90\end{array}$ & $\begin{array}{l}-0007 \\
+.0005\end{array}$ & +.0000 \\
\hline & $\begin{array}{r}-0020 \\
-0011 \\
-.0001\end{array}$ & $\begin{array}{r}.0045 \\
+0010 \\
+\quad 0001\end{array}$ & 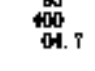 & 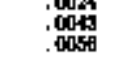 & .0047 \\
\hline $\begin{array}{l}85 \\
96.7\end{array}$ & +.0011 & $\begin{array}{r}-.0009 \\
.0012\end{array}$ & 10 & $\begin{array}{r}.0065 \\
.0032 \\
.0039\end{array}$ & $\begin{array}{l}-0045 \\
.0010\end{array}$ \\
\hline 300 & $\begin{array}{l}00025 \\
0051 \\
0052\end{array}$ & . & 35. B & .018 & $\begin{array}{l}-0003 \\
-0003\end{array}$ \\
\hline 13,2 & $\begin{array}{r}.0012 \\
+.0001\end{array}$ & $\begin{array}{r}-.000 \\
-0000 \\
.00\end{array}$ & 60 & $\begin{array}{r}-0018 \\
-0015\end{array}$ & $\cos 8$ \\
\hline $\begin{array}{l}15 \\
20 \\
20\end{array}$ & $\begin{array}{r}-.0004 \\
.0018 \\
.0030\end{array}$ & $\begin{array}{r}+.0009 \\
.0000 \\
.0016\end{array}$ & $\begin{array}{l}90 \\
800 \\
500\end{array}$ & $\begin{array}{r}.0010 \\
+.0000 \\
+.0000 \\
.000\end{array}$ & $\begin{array}{r}.00003 \\
-.0001 \\
.0000\end{array}$ \\
\hline
\end{tabular}

For the 1940 alkaline solution made from $\mathrm{K}_{2} \mathrm{CrO}_{4}$ in KOH and stored in a ceresin-lined bottle, measurements from time to time showed that changes in absorption were occurring. Data obtained at the end of an 8-year period showed that complete absorption had oceurred below 370 milu. Obviously, therefore, an ordinary glass bottle is better for strorage of a solution of potassium chromate in $\mathrm{KOH}$ than a ceresin-lined bottle. No study of the permanence of the alkoline eolutions stored in alkaliresistant bottles has been made.

It must also be concluded from this study that since the data below $260 \mathrm{~m}_{\mu}$ show possibility of a change in spectral transmittarty after a 6-month period, solutions no older than 6 months should be used for the photometric calibration of a spectrophotometer in this region of the spectrum. On the other hand, for regions above $260 \mathrm{~m}_{\mu}$, it secms afe to une alkaline solutions of either type stored in ordinary glass bottles up to a period of 5 yesers.

\section{Neutral Aqueous Solutions of Potassium Chromate}

Considerable data were obtained on the $B$ solutions (sce gection 2) and a summary is presented here.

The spectral-transmittancy curve of neutral solutions of potassium chroruate was found by Hantzsch [28] to differ somewhat from the alkaline solution, and the results reported here corroborate this finding. From 400 to $500 \mathrm{~m} \mu$ the curve for the neutral solution jo less steep than that of the alkgline solution with a crossing point at ahout $440 m \mu$, above which the transmittancy of the alkaline solution is slightiy higher. Between 300 and $330 \mathrm{~m} \mu$ the neutral solution is slightly lower in tranenittancy than the salkaline solution and slíglitly higher both below and above this range up to $440 \mathrm{~m}_{\mu}$. Below $230 \mathrm{~m}_{\mu}$ this difference is large, the transmittancy at $215 \mathrm{m \mu}$ being 0.40 for the neutral solution and 0.07 for the alkaline. The value (0.07) for this wa velength may be found in table 1, column 4. More weight should be given the 1949 Beckman data below $225 \mathrm{~m}$, because the masurements were obtained under closely controlled conditions of temperature and while the solutions were still fresh, two important controls for this particular region (sections 6 and 7 ). However, this particular value may be somewhat in error due to another cause, namely, the possib] presence of impurities in the $\mathrm{KOH}$.

Over a period of years the nautral solutions were found to be more permanent than the alkaline solutions. Significant changes from 8-year storage in a glass bottle were confined to the spectral region below $230 \mathrm{~m}_{\mu}$; and for storage in a ceresin-lined bottle changes were found only below $260 \mathrm{m \mu}$. A specially pure sample (recrystallized four times) changed still less. The neutral solutions did not calse flaking in the bottles as the alkaline solutions do.

From the standpoint of permanence and convenience in storege the neutral solutions are slightly superior to the alkaline solutions, and had they been found equally reproducible the neutral solutions might be preferable as spectral transmittancy standards instead of the alkaline solutions.

\section{Summary}

Spectrophotometric studies of nentral and alkaline aqueous solutions of potassium chromate extending over a period of years have thown that the alkaline solution is the better suited for use as a spectraltranswiltaney standard in the ultraviolet. The spectral transmittaney of this solution has been determined by five spentrophotometers used according to three different methods, and the finel values are given in table 1 from 220 to $500 \mathrm{~m} \mu$. The finul rezults are also expressed there in terms of absorbancy, $A_{t}=-\log _{10} T$, for a $1-\mathrm{cm}$ cell; molar absorbancy index, $a_{N f}=A_{f} / b c_{i}$ and $\log _{10} a_{H}$. Changeg of transmittancy with temperature were evaluated, and correction data for deviations from the standard temperature of $25^{\circ} \mathrm{C}$ are given in table 3 .

When stored in ordinary glass bottles, the solution is reasonably stable for 5 or 6 years. For work of the highest precision, however, to avoid unsuspected errors from any cause, it is recomnendex that solutions not over 6 months old prepared front chemicals of the highest purity be used as transmittancy standarde.

\section{References}

[1] K. S. Gibson; Geraldine K. Walker, and Mabel E. Brown, Filcen for testing the reliability of spect,rophotolueters, J. Opt. Soc. Am. 24, 55 (1984).

[2] Kazeon B. Gilwon and Marion A. Belknep, Permanence of glase etandards of epectral transmittanes, J. Regesre]t NBS 4, 463 (1950) RP2098. 
[3] W. W. Goblests and R. Btair, Dats on ultraviolet solar redistion and the aolarization of window materials, BS J. Revedre $\}_{1}$ 3, 629 (1920) RPI1a.

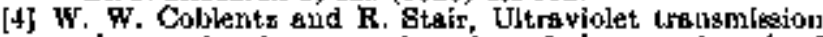
changes in glass as a function of the wavelength of tlue radiation stimulu, BS J. Renearcli 1k, 773 (10\$4) RP744.

[5] We]lsce R. Brote, Cherical kpeetroseopy, 2d ed. (John Wijley of Bous, Itee., 1945).

[6] Photoelectric Spectrometry Group Bulletitn No.4 (J. A. Breckall \& Sonk, Jjverpool, 1951).

[7] Raymund Duvis ajtd $K$. $g$. Gibson, Filters for the reproduction of sunlight and daylight and the determinstion of color temperature, Mjse. Pub. KBS I 14 (1931).

[8] Standards for checking the calibration of spectrophotometers (200 to 1,000 nu), Letter Cireular NBS 920 (1948).

[9] K. \$. Gibson, Bpect.rophoturnet.ry (200 to 1,000 mi]limierous), Cire. NBS 484 (1949).

[10] Analytical abeorption spectrorcopy, edited by M. Ci, Melion (Jolu. Wiley \& Bous, Ine., 1050).

[1]] h. S. Gibson, H. J. MeNicholas, F, P. T. Tyndall, and M. K. Fretisfer witls the cooperstion of W. E. Metliewson, Bureau of Chemistry. The spectral tranamissive properties of dyes, I. Seven permitted fond dyes jn the virible, ultratiolet, aud near infrared, sei. Pap. BS 18, 121 (1922-23) S440.

(12) H. J. MeN icholas, Use of the under-water sperk with the Hilger gector photometer in ultraviolet speetrophoto. ivetr, BS J. Researeh 1, 939 (I 128 ) RP3 3 .

[J3] K. S. Gilbaon, Epectrophotometry at the Buresis of StandaJds, J. Opt. Boc. Am. \$1, 504 (1931).

[14] II. J. MoNichols, Equipment for routine spectsa] transmikgion and reflection measuresturits, BS J. Researeh 1, 703 (1028) FP30.

[15] F. A. Branket, H. T. Wenwel, sud I. B. H. Кupes, Quartz double monochromator with single wavelejgth control, Phys. Rev, sy, 1059 (1940).

[16] A. C. Hardy, History of the design of the recording apeetrophotometer, J, Opt. Soc. An. $38,340(1084)$.
[17] J. L. Michaelaon, Construetion of the General Electric recording "pectrophotometer, J, Opt. Soc. Am. ZB, $365(1938)$.

[18] K. S. Gibson and H. J, Keegan, Ca[jbration and operation of the Gernersl Electric recorting apectrophotometer of the Natjousal Bureau of Standardx, $N$. Opt. Boc. Am. 23, 372 (1938).

[ta] H. H. Cary ardd A. O. Beckmsn, A quarta photoelectrio spectrophotangtes, J. Opt. Eice. Am. 31, 682 (1941).

[20] K. 8. Gibson and Margaret AI. Balcom, Transmission meayurecrents with the Beckrmsu quartz apectrophotometer, J. Rexcarch N BS 38, 601 (1947) RP1798.

[21] Terminding and aymbols for use in ultraviolct, visible, a]d infrsied sbeurpturnetry, Letter Ciroular NBS 857 (1947).

[22] $H$, von $J_{a l b a n}$ and $K$. Siedentopf, Uber die Verwerdung son plotoelektrischer zellen zur Menang der ljehtBbarption in Lüsungen It, Z. physik. Clieın. 1es, $2018(1022)$.

[23] G. Rösiler, Bemerkungen xur Teuhuik der pluotupssphisoher Spectrophotometrle, Ber, ehem. Ges. 6\%, 2606 (1926).

[24] E. C. C. Be]y, R. A. Mortou, and R. W. Riding. The mesalrement of absorptive power, Proc. Roy. Hoc. [A] $113,70 \%(1926)$.

[25] T. R. Hogness, F. P. Zseheile, and A. E. Bidnell, Photoelectric Spectrophotometry-Aul apparatus for the ultreviolet and visible epectral regione: It congtruczion, calibration, and appliestion to cluemical probJems, J. Phys, Chem. 1, 379 (1937).

[26] Interiational Critical Tablea Book Co., lne. New York, T. Y., 1929) (see fig, 4).

[27] W. C. Miller, G. Hare, D. C. Strain, K. P. Cieorge, iI. E. Btitkney, and A. O. Becknisn, A new spectrophotometer employing a glasi Fery prisw, j. Opt. Sor. Am. 38, 377 (1949).

[28] A. Hantzacl, Optiache Lrtersuchungen über die Chromophore ferbjger Salze und sauren, Z. physk. Chem. T2, $362(1910)$.

WabHington; APhiL 2, 1952. 